\title{
CUSTOMER ENGAGEMENT'S ROLE OVER POSITIVE WORD-OF-MOUTH INTENTION: A STUDY ON SMARTPHONES SECTOR
}

\author{
DOI: 10.17261/Pressacademia.2018.871 \\ PAP- V.7-2018(24)-p.150-154
}

\section{Berker Pandir ${ }^{1}$, Ebru Enginkaya ${ }^{2}$}

${ }^{1}$ Istanbul Technical University Department of Management Engineering, Besiktas, Istanbul, Turkey. pandir@itu.edu.tr, ORCID: 0000-0003-3869-2244

${ }^{2}$ Yildiz Technical University Department of Business Administration, Esenler, Istanbul, Turkey. engink@yildiz.edu.tr, ORCID: 0000-0003-1137-3470

To cite this document

Pandir, B., Enginkaya, E. (2018). Customer engagement's role over positive word-of-mouth intention: a study on smartphones sector. PressAcademia Procedia (PAP), V.7, p.150-154.

Permemant link to this document: http://doi.org/10.17261/Pressacademia.2018.871

Copyright: Published by PressAcademia and limited licenced re-use rights only.

\section{ABSTRACT}

Purpose- In this research, researchers have aimed to test relations and roles between customer engagement and positive word-of-mouth intention.

Methodology- This research is a descriptive study and includes the scales of customer engagement and positive word-of-mouth intention which were translated into Turkish and also socio-economic, demographic questions and usage habits. By help of these scales, a survey was formed and applied as an online survey.

Findings- It has been found that there is a significance correlation(Sig=0,00<0.05) between customer engagement and positive word-ofmouth of intention and the output Pearson Correlation Constant was 0.44 . Additionally, there are significant differences in usage habits. Conclusion- It can be interpreted that there is a positive but weak correlation between customer engagement and positive word-of-mouth intention.

Keywords: Customer engagement, positive word-of-mouth intention, smartphones sector, smartphone ownership habits, customer behaviors.

JEL Codes: M31, M30, M10

\section{INTRODUCTION}

With the exponential improvements in the technology, firms gained many possibilities to reach their potential customers. In the meantime, customers also found so many opportunities to contact with the companies which they have been using products or services of. This also makes it difficult to control the communication as it creates an intense network between many customers, firms and their competitors. Altough it increases the difficulty of communication, it allows companies to track their customers' conversations with various tools. Therefore, it would be better to understand the nature of the communication in a better way, along with customers' state of minds and their intentions to spread the positive words to others around them.

Altough both the concepts of customer engagement and positive word-of-mouth are researched separately, researchers of this study has found it fruitful to pursue a bound between these concept. Especially positive word-of-mouth intention has been regarded as a service dominant concept before, it can be interpreted that it can also be applicable to product concepts following products as services and services as products definitions by Porter and Heppelmann (2014). This can also be backed by File et al.'s (1992) viewpoint which states both products and services decide the outcome of the customer participation as positive word-of-mouth intention.

Customer engagement is slightly getting attention from various scholars in the previous years and it could be said that it has evolved into more cognitive and behavioural focus. However, engagement itself still threating the newly born term and researchers believe that there should be more studies to enlight the phenomenon.

\section{LITERATURE REVIEW}

\subsection{Customer Engagement}

Customer engagement is a concept which is broadly researched by scholars all around the world but yet the concept is still to be defined as there are a few conflicting definitions related the concept. In this study, researchers have decided to build their framework onto the 
psychological viewpoint rather than the behavioural viewpoint (Van Doorn et al., 2010; Verhoef et al., 2010), which is mainly inspired by Brodie et al.'s (2011) definition as "A psychological state that occurs by virtue of interactive, cocreative customer experiences with a focal agent/object (e.g., a brand) in focal service relationships.". Vivek et al. (2012) has widened the concept beyond service domain, while also differentiating it from the main term 'engagement' (Pandir B., Yasin B., 2017)

Customer engagement underlines the presence of interactivity, therefore, it is quite different from the viewpoint of Customer Relationship Management(CRM) in this aspect. It is indeed a different path, which ends in 'customer engagement' when the customer is satisfied and there is an emotional bonding (Pansari, A., Kumar, V., 2017). Pansari and Kumar underlines the importance of emotions but Brodie et al.(2011) has a more cognitive viewpoint in customer engagement and therefore the overall framework is still to be defined.

\subsection{WOM}

WOM has been playing a more important role than ever before in influencing consumer decisions. WOM, a form of communication that takes place beyond the control of the companies, is becoming more and more influential in consumer preferences and purchasing decisions than company generated persuasive messages. WOM is crucial for advising and helping consumers about products, services and brands (Kozinets et al.,2010). WOM has become an important method to interact and influence consumers and is a way of information retrieval. Whether online or offline, WOM is a type of interpersonal interaction (Zhang et. al., 2010). WOM is defined as "informal communications directed at other consumers about the ownership, usage, or characteristics of particular goods and services and/or their sellers" (Westbrook, 1987, Lam and Mizerski, 2005). It is also identified as a form of interpersonal communication among consumers for exchange of information in assessment of goods and services (Lang, 2011, Goyette et al., 2010).

Today, as it is difficult to be in direct contact with customers; brands see WOM communication as an opportunity to establish and manage customer loyalty in order to benefit more from customers and maintain longlasting relations (Bowman ve Narayandas, 2001). Mangold et al.(1999) stated that WOM communication is an effective factor in buying behavior and often the buying behavior occurs as a result of WOM communication. According to many diverse communication and marketing tools, WOM is much more trustworthy and has impact on customers' preference and purchase decisions especially for high-involvement products (Goldsmith and Horowitz, 2006, Gu et al., 2012). The information obtained from WOM plays a significant role on purchasing decisions such as coming from reliable sources such as family members and friends, do not include sales messages, and not having to spend time to research brand and verify brand promises (Fang et al, 2011). Ha (2004) indicated that, WOM communication influences consumers' expectations, awareness, perceptions, attitudes, behavior intentions and behaviors.

While WOM can be positive or negative, WOM is more reliable than other forms of communication, and it is obvious that it is influencing consumers to make many decisions in their daily lives. As the increase of digital channels and the spread of communication on the internet, consumers's desire to convey information and ideas to each other is increasing, in this way consumers share their knowledge and experiences with others. Consumers are more likely to buy products after reading user reviews rather than information on corporate websites (Chung and Darke, 2006, Bickart and Schindler, 2001).

\subsubsection{Positive WOM}

Marketers are interested in providing positive WOM, such as novel experiences, or recommendations to others. As an information source, positive WOM is a powerful input into decision making ( $\mathrm{Ng}$. et. al. 2011). Positive WOM communication has been researched and the effects on consumer loyalty and purchase decisions have been investigated and found to be an important factors. Positive WOM communication is correlated with trust, service quality, satisfaction, value, surprise, relationship appraisal, relationship quality and purchase intentions (Ferguson et al., 2010). Customer satisfaction, trust, customer retention and continuous purchasing are possible through positive WOM communication and positive WOM ensures that long-term consumer commitment (Ranaweera and Prabhu, 2003).

Positive word-of-mouth is a powerful tool for brands to promote their products/services. The main objective of the positive WOM strategy initiated by brands is to increase the long-term sales and profits by increasing the customer portfolio and to maintain both the sales and profits and the existence of the brand (Doyle, 2008). Most positive word-of-mouth arises when a customer's expectations are exceeded, and most negative comments come when a customer is disappointed. Dissatisfied customers tend to spread their negative experiences to more people than they do when they have positive experiences. Therefore, marketers and brands are willing to promote and increase positive word-of-mouth communication and avoiding negative word-of-mouth, which can be hazardous to the image of a brand (Gildin, 2003). Also, the structure of social media tools that enables rapid spreading of messages provides great opportunities for brand managers who want to gain a positive impact with positive WOM (Killian and McManus, 2015). With positive WOM, consumers are informed about the positive experiences they have experienced about the brand they bought or the company they prefer to other consumers they are related to. Consumers have a positive attitude towards the product or business in the light of the information they receive, and these positive attitudes can turn into buying behavior (Brown et al., 2005). 


\section{METHODOLOGY}

Following the relevant literature review, researchers of this study have formed this study's theoretical framework as depicted below:

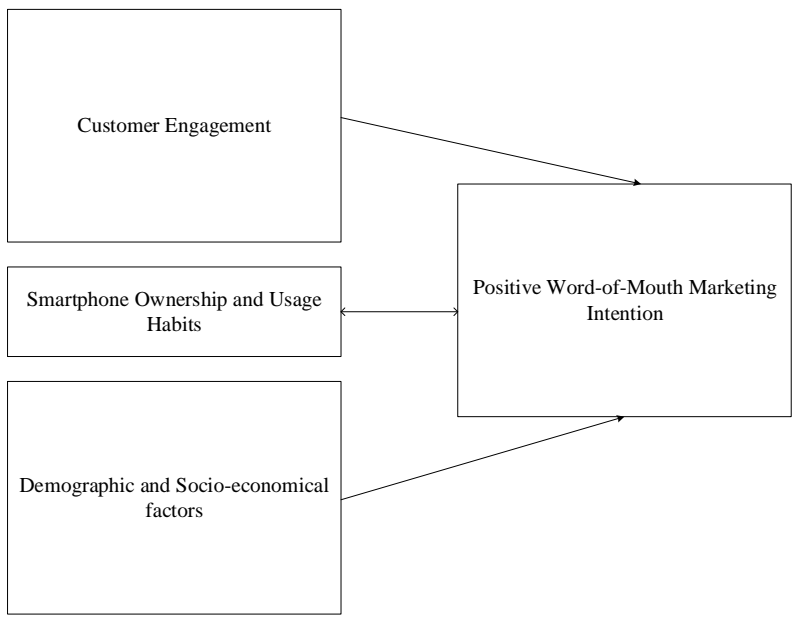

To describe the roles of variables in our study, researchers designed an ampirical research on this field. For data collection, survey method was used. Customer Engagement Scale (Vivek et al., 2012) and Positive Word-of Mouth Intention Scale (Arnett et al., 2003) have been translated from English to Turkish and a small pilot test was conducted to prove that scales are also understandable in and relevant with Turkish language. Smartphones sector has been selected as a relevant area to gather information about. Along with demographic and socio-economical variables, smartphone ownership and usage habits questions have been included. 100 valid responses have been gathered and afterwards ANOVA test and Pearson Correlation Analysis have been used to test our hypotheses. In order to understand what sub groups differ with each other, we used Post-Hoc Tests(Tukey) and we obtained some findings which can be supported by other studies from different aspects.

\section{FINDINGS}

We have analysed the data gathered from a total of 100 respondents(51 women and 49 men) through SPSS. Cronbach-Alpha value for reliability has been $\mathbf{0 . 8 5 7}$, thus, it is reliable and also found valid through relevant analyses. Afterwards, we examined whether the formed factors match the original factors or not and results were satisfying. Therefore, we continued our analyses.

We have observed that there is a significant correlation between customer engagement and levels of customer engagement and positive word-of-mouth intention differ by mainly smartphone ownership and usage habits. Levels of customer engagement and positive word-ofmouth intention has not been observed to differ by socioeconomic and demographic variables in this sector. Customer engagement overall level significantly changes by smartphone ownership duration. Customer who have been using smartphones for more than 5 years have significantly higher level of overall customer engagement considering to ones who have been using 1 or 2 years. We have found that customer engagement overall level doesn't significantly change by owned smartphone brand. Customer engagement overall level significantly changes by what number of smartphone a consumer has been using. Customers who has their first smartphone from the same brand have higher levels of customer engagement compared to 3rd or 4th year owners.

Observed correlation between customer engagement and positive word-of-mouth intention seems to be weak positive correlation (0.44) between customer engagement and positive word-of-mouth intention (sig<0.05 at $95 \%$ confidence interval).

\section{IMPLICATIONS, DISCUSSIONS AND FUTURE RESEARCH}

When smartphone ownership from lasts longer, customer engagement overall level increases. It can be interpreted that having customers connected to the product category longer, it leaves more fingerprints in consumers' minds as the customer feels more involved with the product category.

When someone has bought his/her first smartphone from a specific brand, he/she would have significantly higher levels of customer engagement than others who had bought their third or fourth from the same brand. We can interpret that customer engagement is high at the beginning and getting lower afterwards but customer gets more engaged by the category.

As customer engagement is a psychological construct, its decrease may be interpreted as relationship with the customer transforms to different aspects such as brand love, which is an emotional construct.

As we found out that customer engagement and positive word-of-mouth intention are weak but positively correlated, we may assume that customer engagement is not enough to trigger positive word-of-mouth intention strongly by itself. 
This study could be expanded by conducting this survey with higher sample size and probably in a different sector.

Customer engagement could be research in a model which is including brand love as an emotional construct to better understand positive word-of-mouth intention.

It is recommended to apply this research also in service contexts. Also social media content analysis could be added to estimate both positive and negative word-of-mouth.

\section{REFERENCES}

Arnett, D. B., German, S. D., Hunt, S. D. (2003). The identity salience model of relationship marketing success: the case of nonprofit marketing. Journal of marketing, 67(2), 89-105.

Bickart, B., Schindler R. M. (2001). Internet forums as influential sources of consumer information. Journal of Interactive Marketing, 15, 3, 31-40.

Bowman, D., Narayandas D. (2001). Managing customer- initiated contacts with manufacturers: the impact on share of category requirements and word-of-mouth behavior. Journal of Marketing Research, 38, 3, 281-297.

Brodie, R. J., Hollebeek, L. D. (2011). Advancing and consolidating knowledge about customer engagement. Journal of Service Research, $14(3), 283-284$

Brown, T. J., Barry, T. E., Dacin, P. A., Gunst, R. F. (2005). Spreading the word: investigating antecedents of consumers' positive word-ofmouth intentions and behaviors in a retailing context. Journal of the Academy of Marketing Science, 33, 2, $123-138$.

Chung, C. M. Y., Darke, R. (2006). The consumer as advocate: self-relevance, culture and word-of-mouth. Marketing Letters, 17, $4,269-279$.

Doyle, P. (2008). Value-based marketing. United Kingdom: John Wiley\&Sons, 2. Edition.

Fang, C. H., Lin, T. M. Y., Liu, F., Lin Y. H. (2011). Product type and word of mouth: a dyadic perspective. Journal of Research in Interactive Marketing, 5, 2, 189-202.

Gildin, S. Z. (2003). Understanding the power of word-of-mouth. Revista de Adminitracao Mackenzie, 4, 1, 91-106.

Goldsmith, R. E., Horowitz, D. (2006). Measuring motivations for online opinion seeking. Journal of Interactive Marketing, 6, 2, 2-14.

Goyette, I., Ricard, L., Bergeron, J., Marticotte, F. (2010). e-WoM scale: word-of-mouth measurement scale for services context. Canadian Journal of Administrative Sciences, 27, 1, 5-23.

Gu, B., Park, J., Konana, P. (2012). The impact of external word-of-mouth sources on retailer sales of high-involvement products. Information Systems Research, 2012, 23, 1, 182-196.

$\mathrm{Ha}, \mathrm{H}-\mathrm{Y}$. (2004). Factors influencing consumer perceptions of brand trust online. Journal of Product \& Brand Management, 13, 5, $329-342$.

Killian, G., McManus K. (2015). A marketing communications approach for the digital era: managerial guidelines for social media integration. Business Horizons, 58, 5, 539-549.

Kozinets, R. V., Valck, K., Wilner, S. J. (2010). Networked narratives: understanding word-of-mouth marketing in online communities. Journal of Marketing, 74, 2, 71-89.

Lam, D., Mizerski, D. (2005). The effects of locus of control on word of mouth communication. Journal of Marketing Communications, 11, 3 , 215- 228

Lang, B. (2011). How word of mouth communication varies across service encounters. Managing Service Quality, 21, 6, 583-598.

Mangold, W. G., Miller, F. Brockway, G. R. (1999). Word-of-mouth communication in the service marketplace. The Journal of Service Marketing, 13, 1, 73-89.

Pansari, A., Kumar, V. (2017). Customer engagement: the construct, antecedents, and consequences. Journal of the Academy of Marketing Science, 45(3), 294-311. doi:10.1007/s11747-016-0485-6

Ferguson, R. J., Paulin, M., Bergeron, J. (2010). Customer sociability and the total service experience: antecedents of positive word-ofmouth intentions. Journal of Service Management, Vol. 21 Issue: 1, pp.25-44, https://doi.org/10.1108/09564231011025100

File, K. M., Judd, B. B., Prince, R. A. (1992). Interactive marketing: the influence of participation on positive word-of-mouth and referrals. Journal of Services Marketing, Vol. 6 Issue: 4, pp.5-14, https://doi.org/10.1108/08876049210037113

Pandir, B., Yasin, B. (2017). Brand love and customer engagement's role over brand loyalty. Journal of Management, Marketing and Logistics (JMML), V.4, Iss.4, p.359-365.

Porter, M. E., Heppelmann, J. E. (2014). How smart, connected products are transforming competition. Harvard Business Review, 92(11), 64-88. 
Ranaweera, C., Prabhu, J. (2003). The influence of satisfaction, trust and switching barriers on customer retention in a continuous purchasing setting. International Journal of Service Industry Management, 2003, 14, 4, 374-395.

Ng, S., David, M. E., Dagger, T. S. (2011). Generating positive word-of-mouth in the service experience. Managing Service Quality: An International Journal, Vol. 21 Issue: 2, pp.133-151, https://doi.org/10.1108/09604521111113438

Van Doorn, J., Lemon, K. N., Mittal, V., Nass, S., Pick, D., Pirner, P., Verhoef, P. C. (2010). Customer engagement behavior: theoretical foundations and research directions. Journal of service research, 13(3), 253-266.

Verhoef, P. C., Reinartz, W. J., Krafft, M. (2010). Customer engagement as a new perspective in customer management. Journal of service research, 13(3), 247-252.

Vivek, S. D., Beatty, S. E., Morgan, R. M. (2012). Customer engagement: exploring customer relationships beyond purchase. Journal of Marketing Theory and Practice, vol. 20, no. 2, pp. 122-146.

Westbrook, R. A. (1987). Product/consumption-based affective responses and postpurchase processes. Journal of Marketing Research, $1987,24,3,258-270$

Zhang, J. Q., Craciun, G., Shin, D. (2010). When does electronic word-of-mouth matter? A study of consumer product reviews. Journal of Business Research, 63, 1336-1341. 